\title{
Signatures of adaptation to plant parasitism in nematode genomes
}

\author{
DAVID McK. BIRD ${ }^{1,2}$, JOHN T. JONES ${ }^{3}$, CHARLES H. OPPERMAN ${ }^{2}$, \\ TAISEI KIKUCHI ${ }^{4,5}$ and ETIENNE G. J. DANCHIN ${ }^{6,7,8 *}$ \\ ${ }^{1}$ Bioinformatics Research Center, NC State Univ, Raleigh, NC 27695, USA \\ ${ }^{2}$ Plant Nematode Genetics Group, Dept. of Plant Pathology, NC State Univ, Raleigh, NC 27695, USA \\ 3 Fames Hutton Institute, Invergowrie, Dundee DD2 $5 D A, U K$ \\ ${ }_{5}^{4}$ Division of Parasitology, Faculty of Medicine, University of Miyazaki, Miyazaki 889-1692, Japan \\ ${ }^{5}$ Forestry and Forest Products Research Institute, Tsukuba 305-8687, Fapan \\ ${ }^{6}$ INRA, UMR 1355, Institut Sophia Agrobiotech, F-06903, Sophia-Antipolis, France \\ ${ }^{7}$ Université de Nice Sophia-Antipolis, Institut Sophia Agrobiotech, F-06903, Sophia-Antipolis, France \\ ${ }^{8}$ CNRS, UMR 7254, Institut Sophia Agrobiotech, F-06903, Sophia-Antipolis, France
}

(Received 31 October 2013; revised 23 November 2013; accepted 27 November 2013; first published online 30 fanuary 2014)

S UMMARY

Plant-parasitic nematodes cause considerable damage to global agriculture. The ability to parasitize plants is a derived character that appears to have independently emerged several times in the phylum Nematoda. Morphological convergence to feeding style has been observed, but whether this is emergent from molecular convergence is less obvious. To address this, we assess whether genomic signatures can be associated with plant parasitism by nematodes. In this review, we report genomic features and characteristics that appear to be common in plant-parasitic nematodes while absent or rare in animal parasites, predators or free-living species. Candidate horizontal acquisitions of parasitism genes have systematically been found in all plant-parasitic species investigated at the sequence level. Presence of peptides that mimic plant hormones also appears to be a trait of plant-parasitic species. Annotations of the few genomes of plant-parasitic nematodes available to date have revealed a set of apparently species-specific genes on every occasion. Effector genes, important for parasitism are frequently found among those species-specific genes, indicating poor overlap. Overall, nematodes appear to have developed convergent genomic solutions to adapt to plant parasitism.

Key words: nematodes, genomes, plant parasitism, adaptation, convergence.

\section{INTRODUCTION}

Nematodes are extremely abundant, speciose and numerically dominate in many ecosystems. Although only 23000 species have been formally described, estimates of the total number of species range between $0 \cdot 5$ to more than 10 million (Lambshead, 1993; Lambshead and Boucher, 2003; Blaxter, 2011). While the majority of nematodes are free-living species that feed on bacteria or fungi, or that are predators of other nematodes, the phylum Nematoda also includes parasites of vertebrates, invertebrates and plants. These parasites cause damage to animal and human health as well as to agriculture.

Nematodes may have emerged in the Palaeozoic era from a marine habitat during the Cambrian explosion (550-600 million years ago), but due to the extremely scarce fossil record this remains speculative (van Megen et al. 2009). Although nematode-like fossils from the Precambrian (Proterozoic era) have been reported (Poinar, 2011), the earliest nematode fossil unequivocally identified to date is from the

* Corresponding author: INRA, 400 route des Chappes, BP167, F-06903, Sophia-Antipolis, France. E-mail: etienne.danchin@gmail.com
Palaeozoic era. This ancestral nematode, Palaeonema phyticum, has been dated via radiometry to be $c .396$ million years old (Poinar et al. 2008). Interestingly, this nematode was found in stomatal chambers of a fossilized early land plant, Aglaophyton major, and may thus represent an early plant-parasitic lineage.

Resolving nematode phylogeny on the basis of morphological characters is extremely difficult. Few informative characters can be used to distinguish nematode groups and shared morphological features can be the result of convergent evolution as well as homology. However, the availability of molecular markers, such as small subunit ribosomal DNA (SSU rDNA), has allowed significant advances in assessing the phylogeny of nematodes. The most comprehensive phylogeny published to date is based on SSU rDNA sequences from more than 1200 different nematodes (van Megen et al. 2009). This phylogeny defines 12 distinct clades within the Nematoda. This classification will be used as a reference in this article (Fig. 1).

\section{The emergence of plant parasitism in nematodes}

The remarkable success of nematodes per se, and parasitic forms in particular, can, at least in part, 


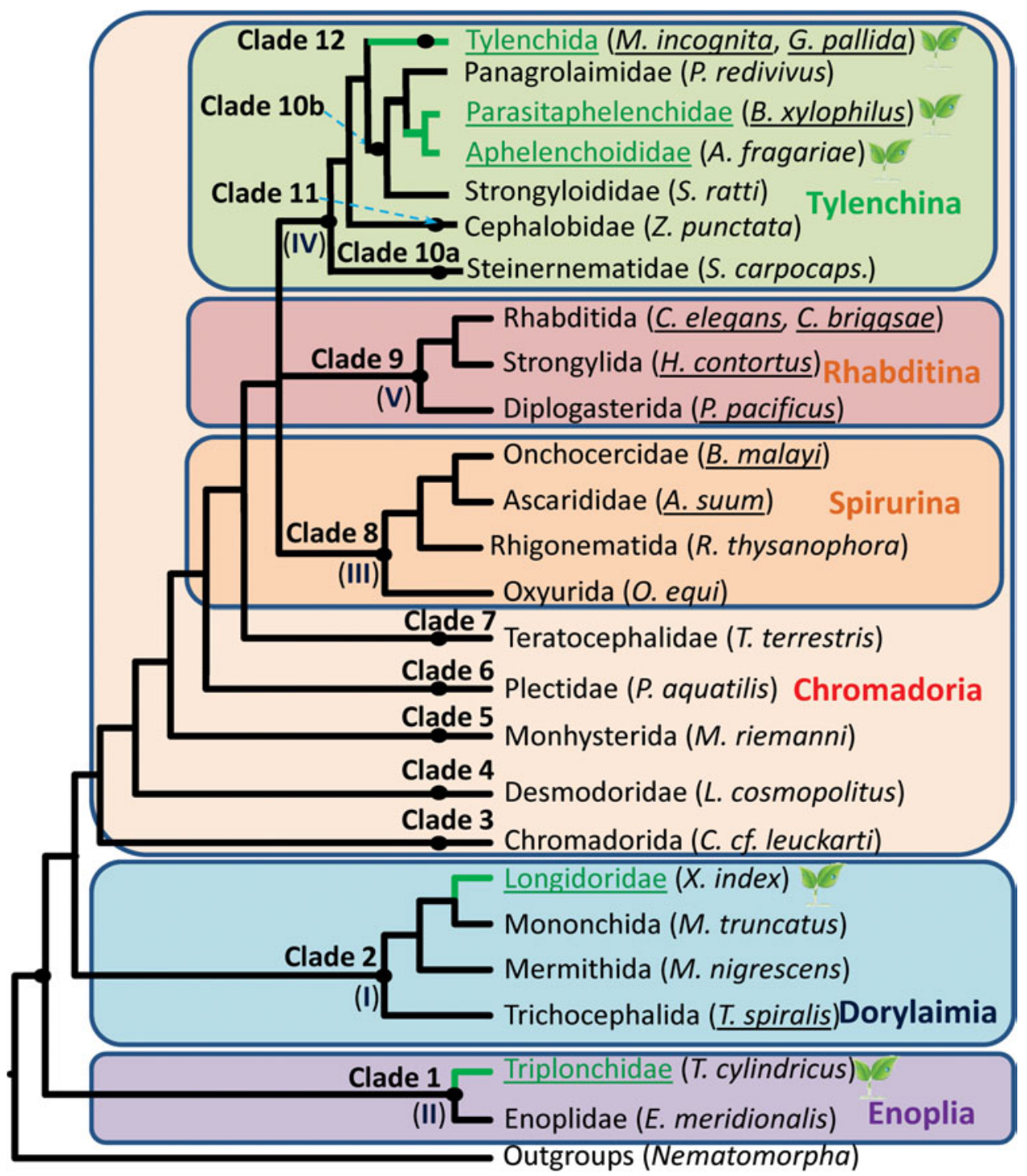

Fig. 1. Schematic phylogeny of Nematoda. Simplified tree topology modified from van Megen et al. (2009), based on SSU rDNA. Clades 1-12 are according to the classification proposed by van Megen et al. (2009). Roman numbers I - V correspond to clades that had been defined in Blaxter et al. (1998). The three major Nematode lineages Enoplia, Dorylaimia and Chromadoria as described in De Ley (2006) are represented by coloured rectangles. The Chromadoria lineage is further subdivided in Spirurina, Rhabditina and Tylenchina. Taxonomic groups in which plant-parasitic species are found are coloured in green and highlighted by a leaf symbol. Underlined species names indicate availability of a genome assembly. Nematomorpha, a group mainly constituted of parasites of arthropods is the closest outgroup to nematodes.

be attributed to two phylum-wide characteristics. Firstly, nematode development has two distinct phases: (1) embryogenesis, in which a worm is made, and (2) post-embryonic development, in which new structures can be added to the preexisting animal; vulval-induction in Caenorhabditis elegans is the canonical example (Sternberg, 2005). A consequence of this is that the morphological (and other) specializations used in parasitism are potentially free to evolve independent of those genes simply needed to specify the basic nematode body plan. Not surprisingly, parasitic nematodes exhibit a wide range of morphologies. The second phylumwide attribute of nematodes is their use of secreted proteins to not only define organismal morphology, but also to construct extra-cellular structures, such as the feeding stylet. Together with the developmental plasticity described above, nematodes are thus primed for rapid adaptation to changing environments.

The phylogenetic tree of nematodes shows that plant-parasitic species are not monophyletic. Instead, plant parasitic nematodes are present in at least 4 of the 12 clades defined by van Megen et al. (2009) and some of these clades are very distant from one another (Fig. 1). For example, the last common ancestor of the plant-parasitic nematodes from clade 12 (Tylenchida) and from clade 1 
(Triplonchidae) is the last common ancestor of all nematodes. In addition, clades containing plantparasitic nematodes are interspersed by clades comprising free-living species, predators and parasites of animals. The current picture suggests that plant parasitism has arisen at least four times independently in nematodes: within clade 1 Triplonchidae, within clade 2 Longidoridae within clade 10b Aphelenchoididae + Parasitaphelenchidae and within clade 12 Tylenchida (Fig. 1). It is also possible that plant parasitism has evolved on several occasions within some of these clades themselves. For example, within the Aphelenchoididae the majority of species are fungivorous but several plant-parasitic species, including Aphelenchoides fragariae and Aphelenchoides besseyi are interspersed between the fungivorous species (Rybarczyk-Mydłowska et al. 2012). It is unclear whether plant-parasitism was the ancestral state at the base of this clade or whether this lifestyle has emerged independently several times within the clade. Interestingly, clades containing plant parasitic nematodes are frequently closely related to those containing fungivorous nematodes, suggesting that plant parasitism may have evolved from fungal feeding nematodes on each occasion.

Although plant parasitism has evolved repeatedly, all plant-parasitic nematodes have at least one common morphological adaptation, the presence of a syringe-like feeding tool, or stylet, which is used to extract nutrients from plant cells and which, in some species, can also be used to introduce nematode-derived molecules into the host. Although functionally analogous, the precise morphology, ontogeny and structure of this feeding tool varies substantially between clades. The feeding tool is termed the stomatostyle in Tylenchida (clade 12) and Aphelenchoidea (clade 10b), the odontostyle in Longidoridae (clade 2) and the onchiostyle in Triplonchidae (clade 1) (Baldwin et al. 2004). The stomatostyle of the Tylenchida and Aphelenchoidea has a lumen that allows nutrients and secretion to pass through but this is not the case for the onchiostlye, where nutrients pass along rather than through the feeding tool. However, while a stylet-like feeding tool seems to be a prerequisite for plant parasitism, several stylet-bearing nematodes are not plant parasites. For example, predators of other nematodes such as Labronema ferox (clade 2), blood-sucking animal parasites like Haemonchus spp. (clade 9) or fungivorous nematodes like Aphelenchoides spp. (clade 10b), all bear a stylet that is used for feeding. Together with the non-homology (in the evolutionary sense) of plant-parasitic nematode stylets, the presence of a stylet in species not associated with plants supports the idea that emergence of this organ is most probably the result of convergent evolution.

Nematodes parasitize plants using a variety of different feeding strategies. At the most basic level, nematodes can be migratory ectoparasites that remain outside the host in the soil and feed on root cells as they are encountered. The majority of species in clade 1 feed using this strategy. Others may be sedentary ectoparasites, which feed for a prolonged period at a single site while remaining outside the roots. Some of these, including several species in clade 2, are also capable of inducing biotrophic feeding structures in their hosts, similar in appearance to the giant cells of root-knot nematodes (below). Endoparasites enter the host and may either be migratory or sedentary. Migratory endoparasites move throughout the plant, causing extensive tissue damage, and feed on the contents of host cells that they encounter. This mode of parasitism is found within clade $10 \mathrm{~b}$ and clade 12 . However, the most damaging species are the sedentary endoparasites. These induce the development of a feeding structure in plant tissues and include the root-knot and cyst nematodes. These sedentary species are responsible for the majority of the estimated $\sim € 100$ billion damage (McCarter, 2009) caused by nematodes to worldwide agriculture every year.

\section{Genomes and transcriptomes of plant-parasitic nematodes}

The genome sequence of the free-living nematode C. elegans was released in 1998 and was the first animal genome sequenced (The $C$. elegans Genome Sequencing Consortium, 1998). It was a further 10 years before the publication of the first plantparasitic nematode genomes. The genomes of the root-knot nematodes Meloidogyne incognita (Abad et al. 2008) and Meloidogyne hapla (Opperman et al. 2008) were also the first genome sequences of any animal that parasitizes plants and offered the first opportunity for comparative genomics between plant-parasitic nematodes. Projects to enhance the assemblies and annotation of both genomes are in progress and for M. hapla, those edits are described in the current public freeze (HapPep5). More recently, the genome sequence of the clade $10 \mathrm{~b}$ species Bursaphelenchus xylophilus, has also been published (Kikuchi et al. 2011). This nematode is the agent responsible for pine wilt disease and has a complex life cycle that includes beetles as vectors and phases in which the nematode feeds on plant tissues and a fungivorous phase during which the nematode feeds on fungi colonizing dead or dying trees (Jones et al. 2008). As a representative of clade 10, it is only distantly related to cyst and root-knot nematodes and, since it is one of the few known plant-parasitic nematodes within the Bursaphelenchus genus, probably represents an independent recent evolution of plant-parasitism. No other publication describing the whole genome of a plant-parasitic nematode has yet been released. However, a draft, partially assembled and un-annotated genome for the soybean cyst nematode Heterodera glycines is available within 
publicly accessible databases. This draft genome was produced and patented as a collaborative effort between two companies (patent WO 2007095469). The genome of the potato cyst nematode Globodera pallida has recently been sequenced by a consortium of researchers in the UK and a manuscript describing its content is under evaluation at the time of writing (J. T. Jones, personal communication). This genome sequence is publicly accessible through: http:// www.sanger.ac.uk/resources/downloads/helminths/ globodera-pallida.html. In addition, genome sequences for two clade 12 migratory endoparasites, Pratylenchus coffeae and Radopholus similis, have recently been sequenced in North Carolina, USA, and a manuscript describing the $P$. coffeae genome has been submitted (C. H. Opperman, personal communication). It is clear that the increased accessibility of high-throughput next-generation sequencing technologies will allow further genome data for a wider range of plant-parasitic nematode species to be obtained in the coming years and that the relatively low costs of obtaining such data will allow nematode species to be selected for sequencing due to their phylogenetic position and biological characteristics rather than just their economic impact. The 959 genomes initiative (Kumar et al. 2012) will provide a broader evolutionary framework for these projects.

In addition to the genome sequences described above, substantial expressed sequence tag (EST) resources are available from a range of plant-parasitic nematodes. While these clearly represent partial data that need to be interpreted with some caution, they represent valuable views of the transcriptomes of nematodes. Efforts have been made to organize and assemble EST data from all nematode groups, including plant parasites, and to make the results of these analyses available to the community. For example, NEMBASE is a constantly updated portal to these resources (Parkinson et al. 2004; Elsworth et al. 2011). Similar resources are available through the nematode.net portal (McCarter et al. 2003; Martin et al. 2011). The shift from Sanger sequencing to 454 and illumina technologies has boosted the throughput of produced transcriptomic data. For example, the transcriptomes of two root lesion nematodes P. coffeae and Pratylenchus thornei were published in 2011 (Haegeman et al. 2011a) and 2012 (Nicol et al. 2012), respectively. The transcriptomes of two nematodes whose host range is limited to monocotyledonous plants, Meloidogyne graminicola, and $A$. besseyi, a clade $10 \mathrm{~b}$ species, have also recently been made available (Haegeman et al. 2013; Kikuchi et al. 2013). The 'established' genomes also benefit from higher throughput methods. For example, more than a billion RNA-seq reads were mapped onto the M. hapla reference genome (VW9), defining 322 new genes, and correcting the models for 2191 of the 14420 previously annotated genes (Y.-L. Guo, unpublished data).
A TREND TOWARDS GENOMEREDUCTION IN PLANT PARASITES?

Although it is possible to try to identify genomic adaptations that are characteristic of plant parasitism in nematodes, it is important to note that the genome data generated so far are restricted to the Tylenchida (clade 12) and Aphelenchoidea (clade 10b). Some of the other clades are represented only by EST data and others have not yet been explored at the sequence level. Thus, it is doubtful that observations made on clades 12 and 10b nematodes can be further generalized to all plant-parasitic lineages.

Genome sizes of the plant-parasitic nematodes sequenced to date are smaller than those of adjacent clade 9 species whose genome sequences have been published. With an assembly size of $53 \mathrm{Mb}$, the $M$. hapla genome is the smallest published so far and about half of the $C$. elegans genome $(100 \mathrm{Mb})$. The migratory endoparasite $P$. coffeae has a genome size of $19.6 \mathrm{Mb}$ as measured by flow cytometry (Leroy et al. 2003) and is considered the smallest animal genome. Although the genome sequence of $M$. incognita is larger $(86 \mathrm{Mb})$, this can be largely attributed to a peculiar genome structure, mainly composed of regions in two copies (Castagnone-Sereno et al. 2013). Decreased gene sets are also observed in plant parasites. The total number of predicted genes in M. hapla (14040) is much lower than in C. elegans $(\sim 20000)$ and genomic and EST sequence analysis indicates $<7500$ predicted genes for $P$. coffeae (C. H. Opperman, personal communication). While the clade $10 \mathrm{~b}$ B. xylophilus is bigger both in genome assembly size $(74 \mathrm{Mb})$ and in the number of predicted genes (18040) than M. hapla, it is still substantially smaller than those of clade 9 species. Similarly, the current $G$. pallida genome assembly is in excess of $120 \mathrm{Mb}$ but no more than 16417 genes are predicted; again fewer than in other sequenced (non-parasitic) nematodes. Although the metrics of M. hapla, $M$. incognita, P. coffeae and B. xylophilus are based on draft genomes, while the $C$. elegans genome is completely finished and annotated, the same observation applies to Pristionchus pacificus, a clade 9 nematode whose draft genome reaches $169 \mathrm{Mb}$ and that encodes 23500 predicted genes (Dieterich et al. 2008). Thus, although a general rule cannot be directly established from a few genomes, there might be a trend towards genome reduction in plant parasitic nematodes compared with free-living nematode species.

Whether a trend towards genome reduction actually occurs in parasites can be also questioned for animal parasites. The genome of Trichinella spiralis, a clade 2 parasite of mammals is only $\sim 64 \mathrm{Mb}$ and contains $\sim 16000$ genes (Mitreva et al. 2011). However, the clade 8 filarial nematodes Brugia malayi, Loa loa and Wuchereria bancrofti all have genome sizes of $\sim 90 \mathrm{Mb}$, comparable to C. elegans, 
though with fewer predicted genes $(\sim 15000)$ (Ghedin et al. 2007; Desjardins et al. 2013). Bucking this trend towards reduction, the genomes of Ascaris suum (clade 8) and Haemonchus contortus (clade 9) are 273 and $\sim 300 \mathrm{Mb}$, respectively (Jex et al. 2011; Laing et al. 2013), which is bigger than those of $C$. elegans or $P$. pacificus and they do not encode substantially fewer genes (18500 and $\sim 22000$, respectively). Hence, although some examples can be cited, there is no evident general trend for genome reduction in parasitic nematodes.

HORIZONTAL ACQUISITION OF PARASITISM GENES FROM NON-METAZOAN DONORS

Perhaps the most striking example of a genomic adaptation to plant parasitism is the presence in nematodes of genes that metabolize the plant cell wall. These genes, usually absent in animal genomes, are present in each of the plant parasitic clades examined to date and are thought to have been acquired by horizontal gene transfer (HGT). HGT is the transmission of genes by means other than direct (vertical) inheritance from the parental generation to the offspring. This phenomenon has been widely documented in prokaryotes. For example, pathogenicity factors and genes providing resistance to antibiotics are exchanged horizontally between bacteria regardless of whether the gene is present in the bacterial genome itself or plasmid-borne (Boucher et al. 2003; Gogarten and Townsend, 2005). HGT in eukaryotes was previously considered to be a minor evolutionary event, particularly in animals. However, numerous cases of HGT from prokaryotes to eukaryotes have now been reported (Andersson, 2005), including from bacteria to animals (Dunning Hotopp, 2011), suggesting that this phenomenon is more prevalent than originally considered. Some cases of HGT from micro-organisms to animals show a clear link between the transferred genes and a biological function in the receiver organism (Schönknecht et al. 2014). The acquisition of genes from bacteria and fungi by plant-parasitic nematodes probably constitutes one of the clearest examples (Danchin, 2011; Haegeman et al. 2011b; Danchin and Rosso, 2012).

The first report of HGT in plant-parasitic nematodes came with the discovery of cellulase genes in two cyst nematodes, the first cellulase genes in any animal. The absence of these secreted cellulases from any other animal genomes available at that time combined with their highest similarity to bacterial cellulases led to the suggestion that they had been acquired via HGT (Smant et al. 1998). The cellulases were subsequently shown to be involved in the degradation of cellulose, one of the major components of the protective plant cell wall, and to play an important role in the invasion of and migration through the host. Similar enzymes were identified in root-knot nematodes soon after (Rosso et al. 1999; Ledger et al. 2006) and in a range of clade 12 migratory endoparasites, (reviewed in Haegeman et al. 2011b). A series of other plant cell walldegrading enzymes were subsequently identified in a variety of plant-parasitic nematodes, including xylanases (Mitreva-Dautova et al. 2006), pectate lyases (Popeijus et al. 2000; Doyle and Lambert, 2002) and polygalacturonases (Jaubert et al. 2002). In addition, expansin-like proteins that disrupt noncovalent bonds in the plant cell wall were also identified (Qin et al. 2004). However, in the absence of an available whole genome sequence for a plantparasitic nematode at that time, the total arsenal of proteins involved in the degradation/softening of the plant cell wall was impossible to assess.

\section{The repertoire of plant cell wall-degrading enzymes in root-knot nematode genomes}

Annotation of Carbohydrate-Active enZymes (CAZymes; Cantarel et al. 2009) in the root-knot nematode genomes allowed an assessment of the full repertoire of plant cell wall-degrading enzymes in a plant-parasitic species to be made. Meloidogyne incognita was found to harbour 61 putative cell walldegrading enzymes (Abad et al. 2008) and M. hapla carries 33 of these (Opperman et al. 2008). In addition to the cellulases, xylanases, pectate lyases and polygalacturonases that were already known, examination of the root-knot nematode genomes also identified novel CAZymes including putative arabinanases (GH43 family) and invertases (GH32 family). Invertases are not cell wall-degrading enzymes but cleave sucrose, the major sugar form circulating in plants, into glucose and fructose, which can be readily metabolized by nematodes. Besides these enzymes, expansin-like proteins were also identified in M. incognita and M. hapla. Analysis of upcoming nematode genomes will soon allow the full repertoire of cell wall-degrading enzymes to be established for additional plant-parasitic nematodes. Representatives of each of these enzyme classes, as well as expansin-like proteins, have already been identified in the genomes and transcriptomes of $P$. coffeae and $R$. similis. However, they occur in greatly reduced numbers, maybe reflecting the different feeding strategies of these migratory endoparasites (C. H. Opperman, personal communication). Both migratory and sedentary endoparasites have to degrade the plant cell wall to penetrate and navigate within plant tissue, but endoparasites also need to modify the plant cell wall for establishment of a feeding site.

Although BLAST-based similarity searching suggested that the genes encoding cell wall degrading and modifying enzymes had been acquired via HGT, only a precise phylogenetic analysis allows the evolutionary history of these proteins to be determined. 


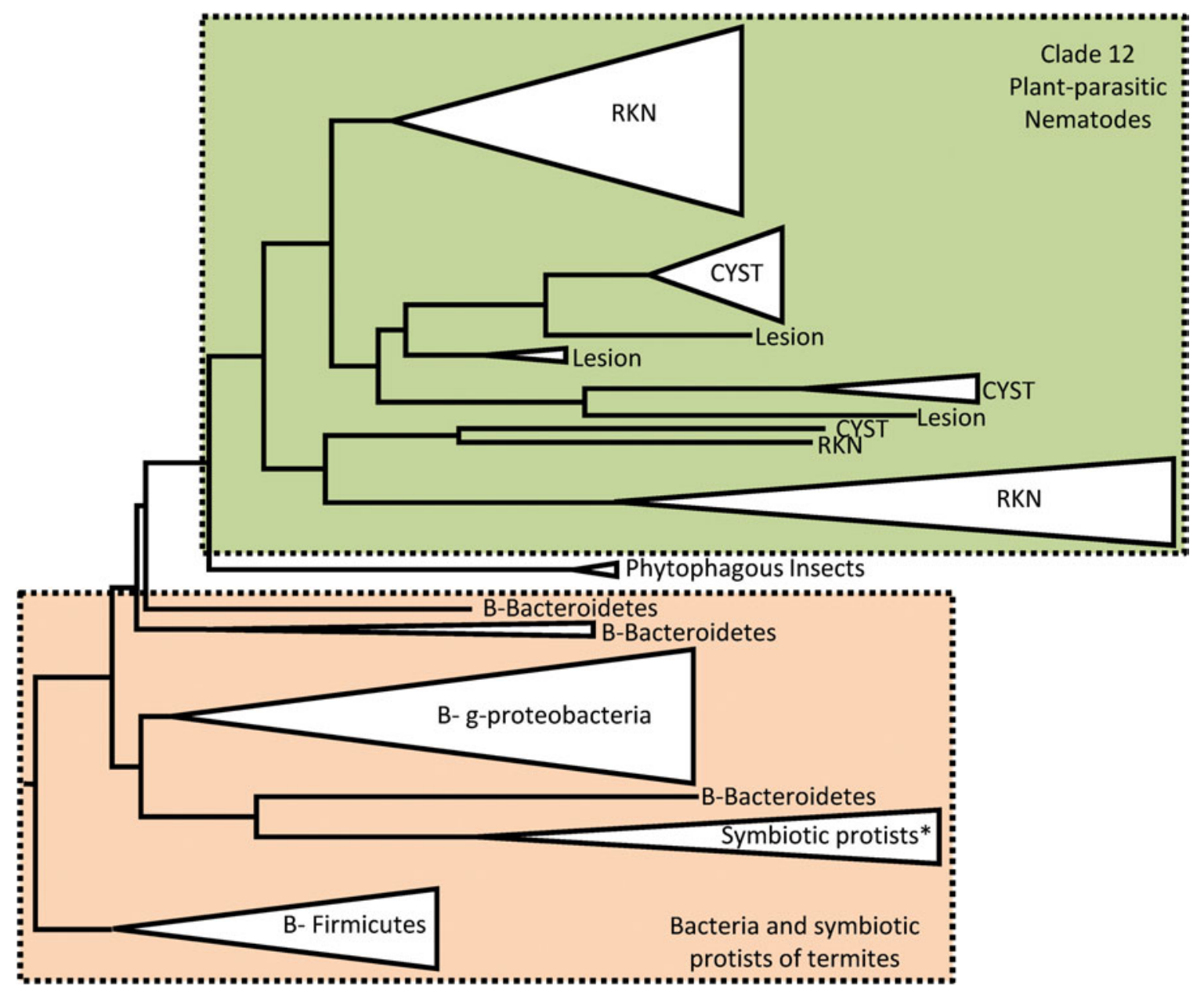

Fig. 2. Phylogenetic relations of nematode GH5 cellulases. This simplified phylogenetic tree is adapted from Danchin et al. (2010) and represents the evolutionary relations between nematode GH5 cellulases and their closest homologues in other species. RKN stands for 'root-knot nematodes', CYST for 'cyst nematodes', Lesion for lesion nematodes (Radopholus similis), B for bacteria. The phytophagous insects represented in this phylogeny are Apriona germari and Psacothea hilaris.

To address this, a systematic phylogenetic analysis was conducted for each of these proteins, using the root-knot nematode genomes as queries (Danchin et al. 2010). Xylanases, pectate lyases, polyglacturonases, candidate arabinases and expansin-like proteins all showed highest similarities to bacterial or fungal proteins. The tree topologies indicating closest homology to microbial proteins were highly supported and their likelihoods were significantly higher than those of alternative topologies. The only exception was for cellulases. Here, the tree topology showed closest homology to cellulases of two herbivorous insects then immediately after, to bacteria (Fig. 2). One possibility is that cellulase genes from bacteria not yet sampled in the sequence database have been transferred twice, once to plant-parasitic nematodes and on another occasion to these herbivorous insects. The absence of cellulase in the many insects in sequence databases argues in favour of this HGT to insects. However, whether these cellulases are ancestral in insects or have been acquired via HGT is still the subject of debate (Watanabe and Tokuda, 2010).

\section{HGT in other nematode clades}

There is evidence suggesting that genes encoding cell wall-degrading enzymes are also present in other clades of plant parasitic nematodes. The most striking example is provided by the presence of GH45 cellulases in clade 10b plant-parasitic nematodes (Aphelenchoidea). Unlike GH5 cellulases, which resemble bacterial enzymes, these GH45 cellulases, described from Bursaphelenchus (Kikuchi et al. 2004) and A. besseyi (Kikuchi et al. 2013) are most similar to fungal cellulases and it seems likely that they have been acquired by HGT from fungi. The genome sequence of $B$. xylophilus revealed that this species harbours $11 \mathrm{GH} 45$ genes but no GH5 gene (Kikuchi et al. 2011). A wider screen of GH45 genes in nematodes and fungi showed nematode GH45 genes have close phylogenetic relationships and conserved gene structure with fungal homologues ('T. Kikuchi, unpublished data). Hence, the acquisition of cellulases, while representing a trait common to several clades, is probably the result of convergent and independent evolution. By contrast, 
families such as the PL3 pectate lyases and expansinlike proteins are found both in clade $10 \mathrm{~b}$ and clade 12 nematodes and whether they have been acquired in an ancestor of the two clades or twice, independently, remains to be established.

In addition, an entirely different class of cellulases (GH12) may also be present in a clade 2 plantparasitic nematode, Xiphinema index (Jones et al. 2005); E. G. J. Danchin, J. T. Jones \& J. Helder, unpublished data). The small size and difficulty of obtaining large quantities of clade 1 nematodes means that no molecular analysis of these nematodes has been carried out to date. Whether cell walldegrading enzymes are also present in this clade is therefore unknown. However, the data available to date suggest that the ability to metabolize the plant cell wall is indeed a common genomic adaptation required for plant-parasitism. It can be hypothesized that HGT has provided the nematodes with new abilities that certainly allowed them to access a new ecological niche. This probable selective advantage associated with the transfer probably was responsible for successful fixation of the foreign gene at the level of populations then of the species itself (Danchin, 2011).

\section{The importance of HGT in the plant-parasitic ability of nematodes}

The plant cell wall-degrading enzymes provide a clear example of acquisitions via HGT in the genome of a plant-parasitic nematode with evident roles in plant parasitism. However, the total contribution of foreign genes to plant-parasitic capacity in nematodes might not be restricted to the degradation of the plant cell wall. An analysis of all the reported cases of HGT in plant-parasitic nematodes from the literature showed that HGT may be associated with processes other than degradation of the plant cell wall (Haegeman et al. 2011b). Genes acquired by HGT may have also contributed to other important processes supporting plant parasitism, including suppression of host defences (e.g. cyanate lyases and chrorismate mutases), nutrient processing (e.g. candidate invertase and enzymes from the salvage pathway of vitamins B1, B5, B6 and B7) or establishment of a feeding structure (e.g. NodL like). A recent systematic search for HGT has shown that, in total, more than $3 \%$ of protein-coding genes in root-knot nematodes may have been acquired from non-animal donors (Paganini et al. 2012).

OTHER NEMATODE PROTEINS REQUIRED FOR INTERACTIONS WITH THE HOST-EFFECTORS

All nematodes that parasitize plants are faced with similar obstacles to obtaining food. As discussed above, each will need to overcome the barrier presented by the host cell wall. All nematodes will also need, to some extent, to overcome or suppress host defence responses although this is clearly of greater importance to endoparasitic species and to those that induce a biotrophic feeding structure than it is to migratory ectoparasites. Indeed, some species need to induce a feeding structure, and these show a wide range of forms and ontogenies. Remarkably, the ability to induce these feeding structures seems to have evolved independently in several clades, including clade 2 (Xiphinema and Longidorus species) and clade 12 . Within clade 12 , this ability has evolved independently in the cyst nematodes (which induce a syncytium) and the root knot nematodes (which induce giant cells). The nematode molecules that mediate these interactions are termed effectors. Various definitions for effectors are used by different authors but for the purposes of this review we consider effectors as nematode molecules that suppress host defences or manipulate the host to allow provision of food to the nematode.

Analysis of the effectors present in various nematode groups shows that they reflect the independent origin of biotrophy in nematodes. For example, a comparison of the effectors present in root-knot and cyst nematodes showed that there are almost no effectors shared between these species (J. T. Jones, personal communication). Supporting these views, ESTs derived from both root-knot nematodes and cyst nematodes show that effector sequences include a very high proportion of pioneer sequences that are not found outside the genus (Gao et al. 2003; Huang et al. 2003). Some of these have evolved to perform essential and highly specific functions. For example, the '19C07' effector from cyst nematodes, which has no similarity to other sequences in the databases, has been shown to interact with an auxin influx transporter (LAX3) and may increase LAX3mediated auxin influx in order to promote syncytium development (Lee et al. 2011).

There are also clear examples of root-knot and cyst nematodes using different molecular strategies to achieve the same functional goal. For example, a secreted calreticulin is used by $M$. incognita to suppress host defence responses (Jaouannet et al. 2013). Although calreticulins are also present in cyst nematodes, there is no evidence to show that these are deployed as effectors. A variety of other molecules including secreted SPRY domain proteins (Postma et al. 2012) and ubiquitin extension proteins (Chronis et al. 2013) fulfil this functional role in cyst nematodes. One feature of effector families in $G$. pallida is that in many cases they are present in large multigene families. The most striking example of this is provided by the SPRYSEC gene family which consists of almost 300 different genes in $G$. pallida but other effector gene families are also expanded (J. T. Jones, personal communication). Since effectors (or their activity) are recognized by host resistance proteins, this expansion of effector 
gene families is likely to result from selection pressure to evade recognition by the host. Consistent with this, one G. pallida SPRYSEC effector has been identified as an avirulence gene, and is recognized by the Gpa2 resistance plant gene (Sacco et al. 2009). Expansion of effector gene families does not seem to be present at a comparable amplitude in the genomes of root-knot nematodes, and whether this represents a common adaptation to plant parasitism remains to be clarified.

NEMATODE-ENCODED PLANT PEPTIDE

HORMONES: A SPECIAL CLASS OF EFFECTOR?

Many processes in vascular plants are controlled by peptide hormones. These proteins, typically 12-15 amino acids long, serve as secreted ligands to mediate cell-to cell communication. The canonical exemplar is the CLAVATA system, in which a peptide (generically termed 'CLE') is secreted into the apoplast to be perceived by transmembrane receptors on adjacent or nearby cells. Arabidopsis encodes at least 600 proteins that fall into this class of receptor, termed Receptor-Like Kinases (RLK), as well as 32 potential ligands. Because the RLK may function as hetero-dimers, the permutations of receptor-ligand complexes is large, presumably affording a high degree of functional plasticity to these regulatory circuits. Genetic evidence implicates components of these circuits as playing a role in nematode parasitism. For example, plants carrying mutations in a well-characterized CLE receptor, the har-1 locus in Lotus japonicus (Sharma et al. 2003; Hirakawa et al. 2008), are hyper-infected by RKN (Lohar and Bird, 2003). Independently, it has been found that polymorphisms in the orthologous locus in tomato correlate with root-knot nematode virulence (Ejima et al. 2011). Collectively, these findings are consistent with the broader hypothesis that rootknot nematodes effect developmental changes necessary for feeding site formation/function, at least in part, by secreting analogues of plant peptide hormones (Bird, 1996).

This hypothesis was first supported by a computational screen (Olsen and Skriver, 2003) that revealed that the SYV-46 peptide from soybean cyst nematode (SCN: H. glycines) likely encoded a CLE-like ligand. SYV-46 had previously been experimentally identified as a protein secreted from the SCN stylet (Gao et al. 2003). Not only does the SYV-46 protein bind a bona fide CLE receptor, CLV2, but the $s y v-46$ gene also is able to complement the Arabidopsis clv3-1 mutant (Wang et al. 2005), strongly implicating this peptide as being a genuine CLE. The $s y v-46$ gene appears to have undergone a recent duplication, as the SCN genome contains a second copy, differing by just 3 bases outside the CLE domain (Davis et al. 2008; Mitchum et al. 2008; Lu et al. 2009). Like plant-encoded CLE, the SCN-encoded CLE mimics contain an additional 'pro' domain between the signal sequence and active peptide. For the native CLE, cleavage of the pro-domain from the active peptide occurs in the apoplast ( $\mathrm{Ni}$ et al. 2011), and presumably serves an additional regulatory function. Recent data confirm the presence of SCN secretions within host cytoplasm, and the variable domain within $\mathrm{HgCLE}$ has been implicated in the transportation of $\mathrm{HgCLE}$ from the host cytoplasm to the apoplast, the presumed site of action. Fusion proteins were constructed by switching the variable domains of native CLE and HgCLE. Based on phenotypic analysis of root development, the variable domains between $\mathrm{HgCLE}$ and native CLE are reported as interchangeable, despite the seemingly contradictory functions (Wang et al. 2010). GFP-tagged antibodies raised against $\mathrm{HgCLE}$ possibly indicate localization to syncytia cytoplasm (i.e. cyst nematode feeding sites). In the same report, evidence derived from the transient over-expression of protein fusions in plants and subsequent bioassays indicates an apoplastic destination.

The role of CLE in the interaction between rootknot nematodes and their hosts has been less studied. Like the $H$. glycines SYV-46 protein, an $M$. incognita protein called 16D10 was initially isolated as an anonymous, putatively secreted protein (Huang et al. 2003) and later computationally identified as having sequence similarity to the CLE motif (Huang et al. 2006). Transgenic over-expression of $16 \mathrm{D} 10$ gave a root developmental response and it was found that the nematode ligand bound to two host SCARECROW-LIKE (SCL) proteins; this result was consistent with the result from a yeast 2-hybrid assay (Huang et al. 2006). SCL are members of the GRAS class of transcription regulators, which play central roles in root meristem specification and also are central to rhizobial nodulation (Hirsch et al. 2009), a process with many molecular and developmental similarities to giant cell induction (Bird, 2004; Weerasinghe et al. 2005). The rather surprising but robust finding of $16 \mathrm{D} 10$ binding to the nuclear protein SCL, rather than a trans-membrane receptor in the apoplast, appears to dismiss this particular gene as encoding a CLE (Mitchum et al. 2008).

Interrogation of the assembled genomes using a double-affine Smith-Waterman algorithm revealed numerous candidate CLE loci in root-knot nematodes (Fig. 3), including many likely false positives. Adding the additional requirements of encoding a secretion signal sequence and a predicted cleavage site upstream of the conserved carboxyl-terminal domain limits the number of CLE in M. hapla to eight genes (D. McK. Bird, personal communication). Each is predicted to encode just these two domains. Absence of the 'pro' domain from the mimics encoded by root-knot nematodes is consistent with the injection of the active form of the peptide hormone directly into the apoplast where they 

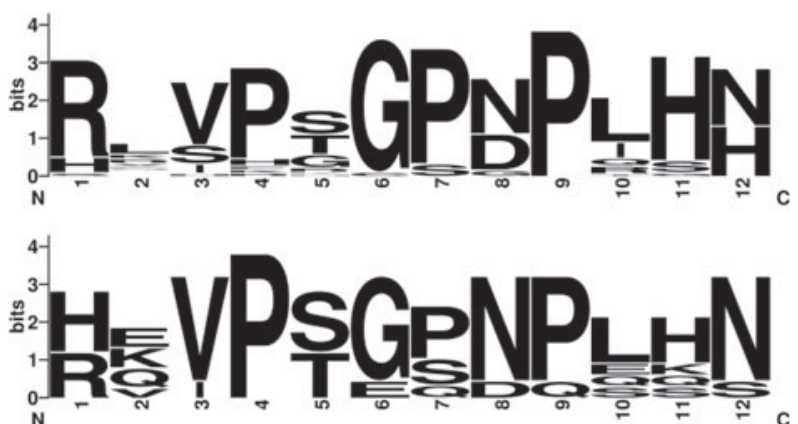

Fig. 3. Nematode CLE motifs. LogoPlots of the 27 unique CLE domains in Arabidopsis (top) and the nine unique candidate CLE domains from M. hapla (bottom). Each $M$. hapla domain was included four times to balance the amplitude.

presumably interact with host RLK and circumvent host regulation. Lesion nematodes, which do not form feeding sites, lack detectable CLE. Functional analyses define two classes, 'A' and 'B'. A-type CLE, which include $\mathrm{CLV} 3$, promote cell differentiation at the meristem by antagonizing WUS and aborting root growth. B-type CLE do not promote cell differentiation at the meristem, but inhibit cell differentiation in Zinnia elegans xylem elements. Members of the different CLE classes likely interact in various manners. Based on sequence similarity, M. hapla and M. incognita encode both types of CLE seen in Arabidopsis.

\section{Root-knot nematode-encoded CEP mimics}

It is assumed that canonical plant peptide hormones are encoded by multiple paralogous genes, with relatively small products ranging from 70-110 amino acids, lacking notable secondary structure (such as cysteine residues) and with high sequence diversity except for the c-terminal domain (Ohyama et al. 2008). Using an algorithm based on these assumptions, a novel, multi-member class of 15-amino acid plant peptide hormones, collectively known as CEP (C-terminally Encoded Peptide) were computationally identified. CEP are expressed in lateral root primordia, and based on the presence of a signal sequence and mass spectrometry data, are postulated to be hormone ligands. The inhibition of lateral root development by transgenic overexpression and the phenocopying effect of exogenous application of synthetic CEP peptide indicate an apoplastic manner of action, congruent with a peptide hormone. In the original report (Ohyama et al. 2008), five CEP were revealed, but our data show an additional protein with five CEP motifs and another with two motifs can be found in the Arabidopsis genome (D. McK. Bird, personal communication). Consistent with a role in regulating lateral root development, CEP are widely distributed across vascular plants, but appear absent from moss

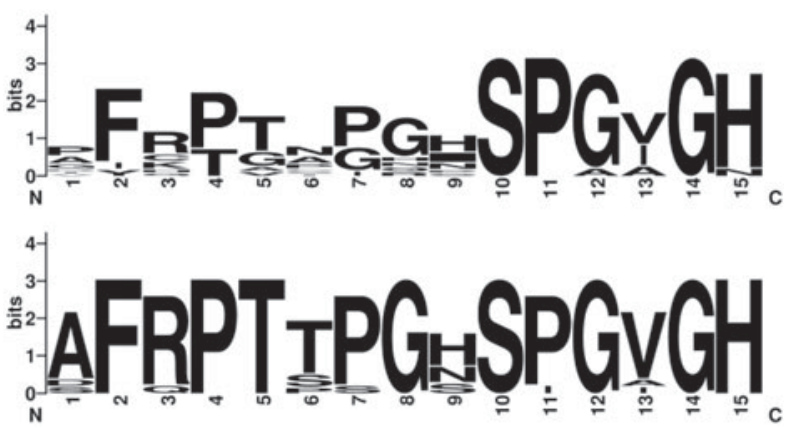

Fig. 4. Meloidogyne hapla CEP domains. LogoPlots of the 12 CEP domains from M. hapla (top) aligned with the 11 unique CEP from Medicago truncatula (bottom).

or unicellular green algae. Interrogation of the $M$. incognita and $M$. hapla genomes revealed 8 and 12 CEP genes, respectively (Fig. 4). CEP are not found in any other animal genera, including cyst and lesion nematodes. Like their plant analogues, each root-knot nematode gene encodes a signal sequence at the amino terminus and single CEP motif at the carboxyl terminus. As is the case for the CLE, plant CEP include a domain between the signal sequence and the hormone domain, which most likely represents a pro-protein domain that is proteolytically removed in the apoplast. Like root-knot nematode CLE, the CEP mimics lack this domain, presumably allowing for the direct delivery of an active peptide into the apoplast.

\section{CLE and CEP loci}

The evolutionary origin of nematode-encoded, plant peptide hormone mimics remains unclear. The notion that they were acquired from their plant hosts (by HGT) is appealing, but the evidence necessary for such inference (i.e. phylogenetic incongruence between species and gene trees) is lacking. Because they encode short sequences, CEP and CLE loci inherently have a restricted phylogenetic signal. This is exacerbated by the functional constraints of the signal sequence and an active hormone domain. Thus, although correspondence can be established between each root-knot nematode CLE (or CEP) and an analogous gene in Arabidopsis, this likely represents functional equivalence rather than reflecting evolutionary homology. We stress however that although evidence for evolutionary homology is lacking, it cannot be ruled out that these gene families arose from a common ancestor (homology) which may have been in a different kingdom (HGT). Nonetheless it has been proposed that these nematode proteins may have arisen de novo (i.e. convergently: Sikora et al. 2005; Mitchum et al. 2008) rather than by HGT and circumstantial evidence, at least for the CEP, may support this. In M. hapla, the 12 CEP-encoding genes are grouped into two tightly linked clusters on a single chromosome. 
Routine annotation of these regions, using genefinding algorithms, trained on large EST datasets, failed to identify any genes in these areas where CEP have now been found. Such gene-sparse regions are highly atypical within the M. hapla genome and unlikely to be coincidental. Comparison of the two CEP loci between sequenced M. hapla isolates (VW8 and VW9) indicate these regions are hypervariable. Collectively, we hypothesize that these are areas of the genome exhibiting rapid evolution, presumably reflecting high diversifying pressure, which in itself may be expanding CEP functions in the parasitic interaction. By contrast CLE, which based on their presence in cyst nematodes as well as root-knot nematodes might to be evolutionarily more ancient, are not surprisingly distributed throughout the rootknot nematode genome. Consistent with expanded function, molecular dynamics simulations of the NMR-solved structures of plant and nematodeencoded CEP (Bobay et al. 2013) indicated that the root-knot nematode ligands have the potential to sample more conformational space than the endogenous peptides (Fig. 5). Perhaps this feature also contributes to the broad host range of these nematodes.

PROTECTION BY THE HOST - PLANT PARASITIC

\section{NEMATODES HAVE REDUCED IMMUNE SYSTEMS}

One genomic consequence of the capacity to reside within a plant seems to be the ability to shed a significant number of genes involved in defence against pathogens. In root-knot nematode genomes, a reduction in the repertoire of genes involved in detoxification, immunity and defence against bacteria and fungi is observed. For example, a very reduced set of chitinases is present as compared with other nematodes as well as a simplified glutathione $\mathrm{S}$ transferase gene family, compared with that present in C. elegans (Abad et al. 2008). A reduced set of chitinases is also present in M. hapla (Opperman et al. 2008). Chitinases are considered as antifungal proteins in nematodes and GSTs are used for detoxification. The genome of G. pallida contains fewer genes involved in detoxification of secondary metabolites as compared with $C$. elegans and genes encoding immune effectors (lysozymes, C-type lectins and chitinases) are also reduced in number (J. T. Jones, personal communication). Is this a feature common to all plant-parasitic nematodes or common to sedentary endoparasites only? First insights into the genomes of $P$. coffeae and $R$. similis also show a reduction of these families involved in defence and immunity (C. H. Opperman, personal communication). These data suggest, paradoxically, that although plant-parasitic nematodes need to avoid or suppress host defence responses, they also derive significant benefit from these host processes in that they are protected from soil-dwelling pathogens
MhCEP11
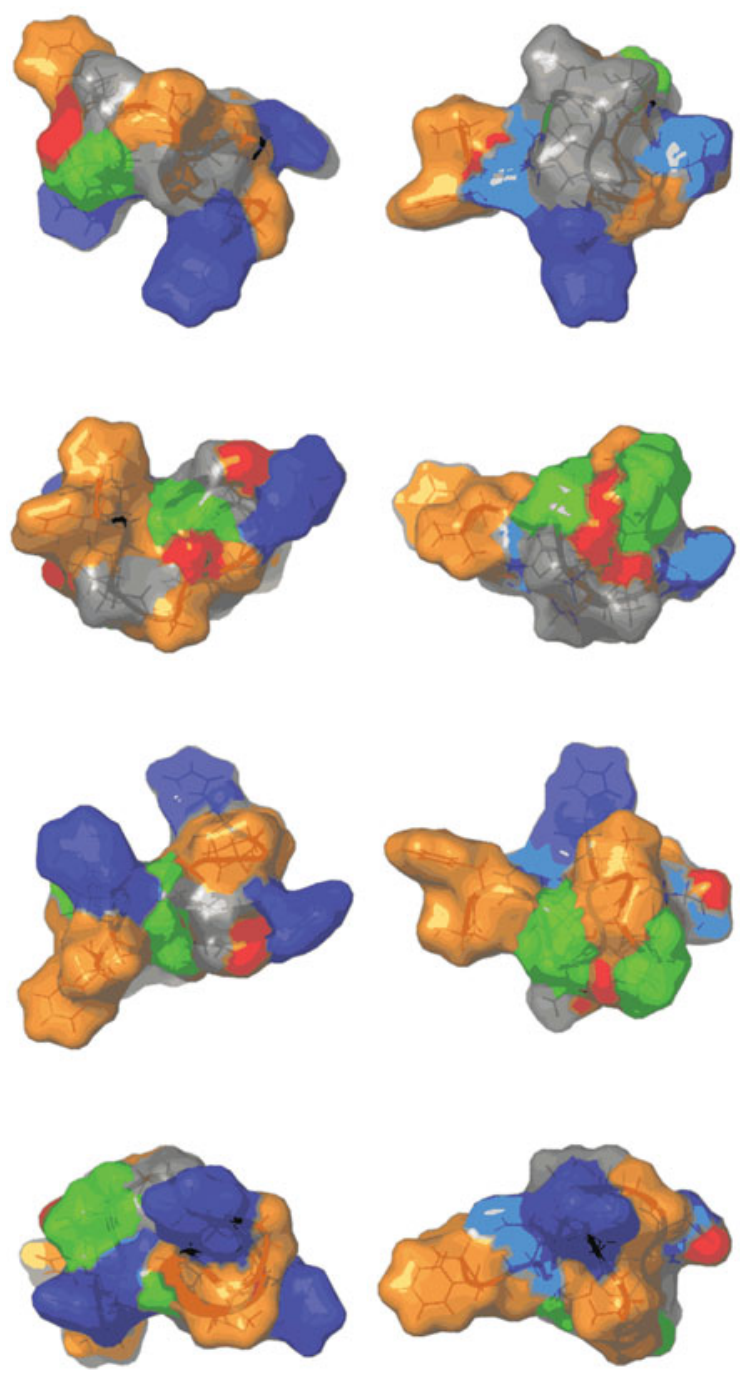

Fig. 5. Comparison of surface characteristics of nematode and plant CEP domains. Surface characteristics of CEP11 from Meloidogyne hapla (MhCEP11) and Medicago truncatula CEP1 (MtCEP1), shown through a $90^{\circ}$ rotation series. Residues are colour-coded by physico-chemical property: Orange $=$ hydrophobic; Blue $=$ positive residues; Cyan $=$ Asp $;$ Green $=$ Pro; Red=Hydroxyl group on Pro.

while inside their host. The impact of this protection can be clearly seen in the genomes of some plantparasites. However, it should also be noted that this is not a constant feature of plant-parasitism. The genome of $B$. xylophilus seems to have an expanded repertoire of genes encoding proteins involved in detoxification processes - this may reflect the fact that this nematode needs to inhabit a plant and an insect at various phases of the life cycle or it may reflect the specific challenges of surviving in woody tissues, which are particularly rich in secondary metabolites (Kikuchi et al. 2011).

Interestingly, a reduction in the set of antibacterial genes was observed in the clade 8 animal-parasitic nematodes $L$. loa, $B$. malayi and $W$. bancrofti 
(Desjardins et al. 2013). However, such a reduction of antibacterial repertoire was not observed in A. suum, suggesting this might be a specificity of the above-mentioned filarial nematodes. Further supporting this filarial specificity, no reduction of antibacterial, detoxification or immune repertoires have been mentioned in the genome papers of the animal parasites T. spiralis (Mitreva et al. 2011) and H. contortus (Laing et al. 2013).

\section{MODES OF REPRODUCTION - THE INFLUENCE OF HOST RANGE AND THE EFFECTS ON \\ NEMATODE GENOMES}

The host range of plant-parasitic nematodes has an enormous influence on their biology, including their mode of reproduction (Blok et al. 2008) and this, in turn may have a significant impact on genome structure. Most plant pathogens, including nematodes, are unable to develop on most plants and therefore have a restricted host range. Many cyst nematodes follow this rule, with each species able to infect a relatively narrow range of plants. The host is often reflected in species names (potato cyst nematode, soybean cyst nematode and so on). As a consequence, a cyst nematode developing on a host is likely to encounter another individual of the same species on that host and reproduction is most often sexual in these species. However, some root knot nematodes, including $M$. incognita have extraordinarily broad host ranges. Although the whole host range of $M$. incognita, as a species, might be the result of an assemblage of populations that have each a more restricted collection of compatible hosts, most tested populations have multiple host plants (Robertson et al. 2006; Castagnone-Sereno et al. 2013). Root-knot nematodes show a striking diversity of reproductive modes, ranging from strict sexual reproduction (amphimixis), facultative sexual reproduction (meiotic parthenogenesis) to fully asexual reproduction (mitotic parthenogenesis). Interestingly, root-knot nematodes with the broadest host ranges, like $M$. incognita, reproduce by mitotic parthenogenesis, which ensures that reproduction can occur in the absence of a partner. This reproductive mode does not require finding a mate and allows a rapid and effective exploitation of food resources. These observations suggest that there is a link between the mode of reproduction and the host range. The mode of reproduction itself has consequences for the genome structure. Absence of meiosis relaxes pressure for homologous chromosome pairing and allows them to substantially diverge from one another. Supporting this view, the genome of $M$. incognita is present in pairs of regions showing a high average divergence of $7 \%$ at the nucleotide level. It is hypothesized that this high divergence might allow functional divergence between gene copies thus providing a mechanism of plasticity/variability in the absence of inter-individual genetic exchanges. Whether these genomic singularities are common in strict parthenogenetic plant-parasitic nematodes will be interesting to assess as new genomes become available.

A point that is common to cyst nematodes and root-knot nematodes is sex determination. In both groups of species, sex determination depends on environmental conditions with adverse conditions leading to more males being produced in both cases. In facultative parthenogenetic species, it is hypothesized that the higher proportion of males generated during adverse conditions allows for more sexual reproduction to occur. Promoting genetic exchange between individuals, sexual reproduction would allow new combinations of alleles to emerge, with enhanced probability of including new genotypes able to adapt. Here again, while the genetics underlying this process is not described it is possible that this mode of sex determination, determined by the environment, has emerged independently in a convergent manner.

\section{CONCLUSIONS}

Plant parasitic nematodes can collectively infest virtually any human-cultivated plant and cause dramatic damage to worldwide agriculture. They can therefore be considered as evolutionarily successful parasites. This feeding mode has emerged several times independently in nematodes. Interestingly, the challenges constituted by infesting a live host plant appear to have led to parallel convergent evolution of similar solutions. For instance, at a morphological level, all plant-parasitic nematodes possess a syringe-like stylet to feed from plant cells. This organ appears to have been invented independently in each clade with different ontogeny and fine structure. Exploring recent genomic data, we have shown here that, just like observations at the morphologic level, convergent genomic adaptations also appear to have occurred independently in different lineages of plant-parasitic nematodes. Acquisition of parasitism genes via HGT appear to be an adaptation common to all species investigated at the sequence level. Effector proteins, involved in repression of plant defence systems and establishment of a successful biotrophic interaction are encoded by the genomes of various plant-parasitic nematodes. However, these effector proteins are poorly conserved from one nematode species to another and mostly lineage-specific, suggesting that they also have emerged independently multiple times to circumvent similar plant host challenges. Mimicry of plant peptide hormones is a common feature of cyst nematodes and root-knot nematodes, two independently evolved lineages of sedentary endoparasitic nematodes. Interestingly, there is no evident orthological relationship between cyst and root-knot 
nematode mimics, indicating, once again, a probable convergent evolution. Overall, while some features, such as the acquisition of parasitism genes via HGT, reduction of the repertoire of genes for detoxification and defence, the presence of effector genes or of plant peptide mimics appear as common genomic signatures, looking into each of these features in more detail reveals lack of true homology and suggests independent emergence of convergent adaptations to plant parasitism within the different nematode lineages.

Interestingly, several parallels can be drawn between the genomes of plant-parasitic nematodes and those of other phytopathogens or phytoparasites. For instance, acquisition via HGT of plant cell walldegrading enzymes and other parasitism genes have also been observed in plant-parasitic oomycetes (Judelson, 2012). Similarly, phytoparasitic fungi have acquired genes involved in pathogenesis from bacteria via HGT too (Gardiner et al. 2012). Filamentous fungi as well as oomycetes also encode genus or lineage-specific effectors secreted in planta that assist different processes enabling parasitism (Oliva et al. 2010). Hence, these two features appear to represent more general adaptive convergences to plant parasitism.

\section{ACKNOWLEDGEMENTS}

E.G.J. Danchin would like to thank Dr Andrew Jackson from the University of Liverpool as well as Drs Matt Berriman and James Cotton from the Wellcome Trust Sanger Institute for their invitation to a meeting entitled 'The evolution of parasite genomes and the origins of parasitism'. This meeting was a founder event for the writing of the current review and influenced my views of parasites genomics.

\section{FINANCIAL SUPPORT}

Each author is, or was, at the time of the work, a paid employee of their affiliated organization. The James Hutton Institute receives funding from the Scottish Government. TK is funded by JSPS KAKENHI Grant Numbers 20353659 and 23248024 .

\section{REFERENCES}

Abad, P., Gouzy, J., Aury, J.-M., Castagnone-Sereno, P., Danchin, E. G. J., Deleury, E., Perfus-Barbeoch, L., Anthouard, V., Artiguenave, F., Blok, V.C., Caillaud, M.-C., Coutinho, P.M., Dasilva, C., Luca, F.D., Deau, F., Esquibet, M., Flutre, T., Goldstone, J. V., Hamamouch, N., Hewezi, T., Jaillon, O., Jubin, C., Leonetti, P., Magliano, M., Maier, T. R., Markov, G. V., McVeigh, P., Pesole, G., Poulain, J., Robinson-Rechavi, M., Sallet, E., Ségurens, B. Steinbach, D., Tytgat, T., Ugarte, E., van Ghelder, C., Veronico, P., Baum, T. J., Blaxter, M., Bleve-Zacheo, T., Davis, E. L., Ewbank, J. J., Favery, B., Grenier, E., Henrissat, B., Jones, J. T., Laudet, V., Maule, A. G., Quesneville, H., Rosso, M.-N., Schiex, T., Smant, G., Weissenbach, J. and Wincker, P. (2008). Genome sequence of the metazoan plant-parasitic nematode Meloidogyne incognita. Nature Biotechnology 26, 909-915. doi: 10.1038/nbt.1482.

Andersson, J. O. (2005). Lateral gene transfer in eukaryotes. Cellular and Molecular Life Sciences 62, 1182-1197.

Baldwin, J. G., Nadler, S. A. and Adams, B. J. (2004). Evolution of plant parasitism among nematodes. Annual Review of Phytopathology 42, 83-105.
Bird, D. M. (1996). Manipulation of host gene expression by root-knot nematodes. Fournal of Parasitology 82, 881-888.

Bird, D. M. (2004). Signaling between nematodes and plants. Current Opinion in Plant Biology 7, 372-376. doi: 10.1016/j.pbi.2004.05.005.

Blaxter, M. (2011). Nematodes: the worm and its relatives. PLoS Biology 9, e1001050. doi: 10.1371/journal.pbio.1001050.

Blaxter, M. L., Ley, P.D., Garey, J. R., Liu, L.X., Scheldeman, P., Vierstraete, A., Vanfleteren, J. R., Mackey, L. Y., Dorris, M., Frisse, L. M., Vida, J. T. and Thomas, W. K. (1998). A molecular evolutionary framework for the phylum Nematoda. Nature 392, 71-75. doi: $10.1038 / 32160$

Blok, V.C., Jones, J. T., Phillips, M.S. and Trudgill, D. L. (2008). Parasitism genes and host range disparities in biotrophic nematodes: the conundrum of polyphagy versus specialisation. Bioessays 30, 249-259.

Bobay, B., DiGennaro, P., Scholl, E., Imin, N., Djordjevic, M. and Bird, D. M. (2013). Solution NMR studies of the plant peptide hormone CEP inform function. FEBS Letters 587, 3979-3985. doi: 10.1016/j. febslet.2013.10.033.

Boucher, Y., Douady, C. J., Papke, R. T., Walsh, D. A., Boudreau, M. E., Nesbo, C. L., Case, R. J. and Doolittle, W. F. (2003). Lateral gene transfer and the origins of prokaryotic groups. Annual Review of Genetics 37, 283-328.

Cantarel, B. L., Coutinho, P. M., Rancurel, C., Bernard, T., Lombard, V. and Henrissat, B. (2009). The Carbohydrate-Active EnZymes database (CAZy): an expert resource for glycogenomics. Nucleic Acids Research 37, D233-D238.

Castagnone-Sereno, P., Danchin, E. G., Perfus-Barbeoch, L. and Abad, P. (2013). Diversity and evolution of root-knot nematodes, genus Meloidogyne: new insights from the genomic era. Annual Review of Phytopathology 51, 203-220. doi: 10.1146/annurev-phyto-082712-102300. Chronis, D., Chen, S., Lu, S., Hewezi, T., Carpenter, S. C. D., Loria, R., Baum, T. J. and Wang, X. (2013). A ubiquitin carboxyl extension protein secreted from a plant-parasitic nematode Globodera rostochiensis is cleaved in planta to promote plant parasitism. Plant Fournal: for Cell and Molecular Biology 74, 185-196. doi: 10.1111/tpj.12125. Danchin, E. G., Rosso, M. N., Vieira, P., de Almeida-Engler, J., Coutinho, P. M., Henrissat, B. and Abad, P. (2010). Multiple lateral gene transfers and duplications have promoted plant parasitism ability in nematodes. Proceedings of the National Academy of Sciences USA 107, 17651-17656.

Danchin, É. G. J. (2011). What nematode genomes tell us about the importance of horizontal gene transfers in the evolutionary history of animals. Mobile Genetic Elements 1, 269-273.

Danchin, E. G. J. and Rosso, M.-N. (2012). Lateral gene transfers have polished animal genomes: lessons from nematodes. Frontiers in Cellular and Infection Microbiology 2, art. 27. doi: 10.3389/fcimb.2012.00027.

Davis, E. L., Hussey, R. S., Mitchum, M. G. and Baum, T. J. (2008). Parasitism proteins in nematode-plant interactions. Current Opinion in Plant Biology 11, 360-366. doi: 10.1016/j.pbi.2008.04.003.

De Ley, P. (2006). A quick tour of nematode diversity and the backbone of nematode phylogeny. WormBook: the Online Review of C. elegans Biology 1-8. doi: 10.1895/wormbook.1.41.1.

Desjardins, C. A., Cerqueira, G. C., Goldberg, J. M., Hotopp, J. C. D., Haas, B. J., Zucker, J., Ribeiro, J. M. C., Saif, S., Levin, J. Z., Fan, L., Zeng, Q., Russ, C., Wortman, J. R., Fink, D. L., Birren, B.W. and Nutman, T.B. (2013). Genomics of Loa loa, a Wolbachia-free filarial parasite of humans. Nature Genetics 45, 495-500. doi: 10.1038/ ng. 2585 .

Dieterich, C., Clifton, S.W., Schuster, L. N., Chinwalla, A., Delehaunty, K., Dinkelacker, I., Fulton, L., Fulton, R., Godfrey, J., Minx, P., Mitreva, M., Roeseler, W., Tian, H., Witte, H., Yang, S. P., Wilson, R. K. and Sommer, R. J. (2008). The Pristionchus pacificus genome provides a unique perspective on nematode lifestyle and parasitism. Nature Genetics 40, 1193-1198.

Doyle, E. A. and Lambert, K. N. (2002). Cloning and characterization of an esophageal-gland-specific pectate lyase from the root-knot nematode Meloidogyne javanica. Molecular Plant Microbe Interactions 15, 549-556.

Dunning Hotopp, J. C. (2011). Horizontal gene transfer between bacteria and animals. Trends in Genetics 27, 157-163. doi: 10.1016/j.tig.2011.01.005. Ejima, C., Uwatoko, T., Ngan, B. T., Honda, H., Shimizu, N., Kiyohara, S., Hamasaki, R. and Sawa, S. (2011). SNPs of CLAVATA receptors in tomato, in the context of root-knot nematode infection. Nematological Research 41, 35-40.

Elsworth, B., Wasmuth, J. and Blaxter, M. (2011). NEMBASE4: the nematode transcriptome resource. International Fournal for Parasitology 41, 881-894. doi: 10.1016/j.ijpara.2011.03.009. 
Gao, B., Allen, R., Maier, T., Davis, E. L., Baum, T. J. and Hussey, R. S. (2003). The parasitome of the phytonematode Heterodera glycines. Molecular Plant Microbe Interactions 16, 720-726.

Gardiner, D. M., McDonald, M. C., Covarelli, L., Solomon, P.S., Rusu, A. G., Marshall, M., Kazan, K., Chakraborty, S., McDonald, B. A. and Manners, J. M. (2012). Comparative pathogenomics reveals horizontally acquired novel virulence genes in fungi infecting cereal hosts. PLoS Pathogens 8, e1002952. doi: 10.1371/journal. ppat.1002952.

Ghedin, E., Wang, S., Spiro, D., Caler, E., Zhao, Q., Crabtree, J., Allen, J. E., Delcher, A. L., Guiliano, D. B., Miranda-Saavedra, D., Angiuoli, S. V., Creasy, T., Amedeo, P., Haas, B., El-Sayed, N. M., Wortman, J. R., Feldblyum, T., Tallon, L., Schatz, M., Shumway, M., Koo, H., Salzberg, S. L., Schobel, S., Pertea, M., Pop, M., White, O., Barton, G. J., Carlow, C. K., Crawford, M. J., Daub, J., Dimmic, M. W., Estes, C. F., Foster, J. M., Ganatra, M., Gregory, W. F., Johnson, N. M., Jin, J., Komuniecki, R., Korf, I., Kumar, S., Laney, S., Li, B. W., Li, W., Lindblom, T. H., Lustigman, S., Ma, D., Maina, C. V., Martin, D. M., McCarter, J.P., McReynolds, L., Mitreva, M., Nutman, T. B., Parkinson, J., Peregrin-Alvarez, J. M., Poole, C., Ren, Q., Saunders, L., Sluder, A. E., Smith, K., Stanke, M., Unnasch, T. R., Ware, J., Wei, A. D., Weil, G., Williams, D. J., Zhang, Y., Williams, S. A., Fraser-Liggett, C., Slatko, B., Blaxter, M. L. and Scott, A. L. (2007). Draft genome of the filarial nematode parasite Brugia malayi. Science 317, 1756-1760.

Gogarten, J. P. and Townsend, J. P. (2005). Horizontal gene transfer, genome innovation and evolution. Nature Reviews Microbiology 3, 679-687. doi: 10.1038/nrmicro1204

Haegeman, A., Joseph, S. and Gheysen, G. (2011a). Analysis of the transcriptome of the root lesion nematode Pratylenchus coffeae generated by 454 sequencing technology. Molecular and Biochemical Parasitology 178, 7-14. doi: 10.1016/j.molbiopara.2011.04.001.

Haegeman, A., Jones, J. T. and Danchin, E. G. (2011b). Horizontal gene transfer in nematodes: a catalyst for plant parasitism? Molecular Plant Microbe Interactions 24, 879-887. doi: 10.1094/MPMI-03-11-0055.

Haegeman, A., Bauters, L., Kyndt, T., Rahman, M. M. and Gheysen, G. (2013). Identification of candidate effector genes in the transcriptome of the rice root knot nematode Meloidogyne graminicola. Molecular Plant Pathology 14, 379-390. doi: 10.1111/mpp.12014.

Hirakawa, Y., Shinohara, H., Kondo, Y., Inoue, A., Nakanomyo, I., Ogawa, M., Sawa, S., Ohashi-Ito, K., Matsubayashi, Y. and Fukuda, H. (2008). Non-cell-autonomous control of vascular stem cell fate by a CLE peptide/receptor system. Proceedings of the National Academy of Sciences USA 105, 15208-15213. doi: 10.1073/pnas. 0808444105

Hirsch, S., Kim, J., Muñoz, A., Heckmann, A. B., Downie, J. A. and Oldroyd, G.E.D. (2009). GRAS proteins form a DNA binding complex to induce gene expression during nodulation signaling in Medicago truncatula. Plant Cell Online 21, 545-557. doi: 10.1105/tpc.108. 064501.

Huang, G., Gao, B., Maier, T., Allen, R., Davis, E. L., Baum, T. J. and Hussey, R. S. (2003). A profile of putative parasitism genes expressed in the esophageal gland cells of the root-knot nematode Meloidogyne incognita. Molecular Plant Microbe Interactions 16, 376-381.

Huang, G., Dong, R., Allen, R., Davis, E. L., Baum, T. J. and Hussey, R. S. (2006). A root-knot nematode secretory peptide functions as a ligand for a plant transcription factor. Molecular Plant Microbe Interactions 19, 463-470.

Jaouannet, M., Magliano, M., Arguel, M. J., Gourgues, M., Evangelisti, E., Abad, P. and Rosso, M. N. (2013). The root-knot nematode calreticulin Mi-CRT is a key effector in plant defense suppression. Molecular Plant Microbe Interactions 26, 97-105. doi: 10.1094/ MPMI-05-12-0130-R.

Jaubert, S., Laffaire, J. B., Abad, P. and Rosso, M. N. (2002). A polygalacturonase of animal origin isolated from the root-knot nematode Meloidogyne incognita. FEBS Letters 522, 109-112.

Jex, A. R., Liu, S., Li, B., Young, N. D., Hall, R.S., Li, Y., Yang, L., Zeng, N., Xu, X., Xiong, Z., Chen, F., Wu, X., Zhang, G., Fang, X., Kang, Y., Anderson, G. A., Harris, T. W., Campbell, B. E., Vlaminck, J., Wang, T., Cantacessi, C., Schwarz, E. M., Ranganathan, S., Geldhof, P., Nejsum, P., Sternberg, P. W., Yang, H., Wang, J., Wang, J. and Gasser, R. B. (2011). Ascaris suum draft genome. Nature 479, 529-533. doi: 10.1038/nature10553.

Jones, J. T., Furlanetto, C. and Kikuchi, T. (2005). Horizontal gene transfer from bacteria and fungi as a driving force in the evolution of plant parasitism in nematodes. Nematology 7, 641-646.

Jones, J. T., Moens, M., Mota, M., Li, H. and Kikuchi, T. (2008). Bursaphelenchus xylophilus: opportunities in comparative genomics and molecular host-parasite interactions. Molecular Plant Pathology 9, 357-368. doi: 10.1111/j.1364-3703.2007.00461.x.

Judelson, H.S. (2012). Dynamics and innovations within oomycete genomes: insights into biology, pathology, and evolution. Eukaryotic Cell 11, 1304-1312. doi: 10.1128/EC.00155-12

Kikuchi, T., Jones, J. T., Aikawa, T., Kosaka, H. and Ogura, N. (2004). A family of glycosyl hydrolase family 45 cellulases from the pine wood nematode Bursaphelenchus xylophilus. FEBS Letters 572, 201-205.

Kikuchi, T., Cotton, J. A., Dalzell, J. J., Hasegawa, K., Kanzaki, N., McVeigh, P., Takanashi, T., Tsai, I. J., Assefa, S. A., Cock, P. J. Otto, T. D., Hunt, M., Reid, A. J., Sanchez-Flores, A., Tsuchihara, K., Yokoi, T., Larsson, M. C., Miwa, J., Maule, A. G., Sahashi, N., Jones, J. T. and Berriman, M. (2011). Genomic insights into the origin of parasitism in the emerging plant pathogen Bursaphelenchus xylophilus. PLoS Pathogens 7, e1002219. doi: 10.1371/journal.ppat.1002219.

Kikuchi, T., Cock, P. J., Helder, J. and Jones, J. T. (2013) Characterisation of the transcriptome of Aphelenchoides besseyi and identification of a GHF 45 cellulase. Nematology. In press. http:// booksandjournals.brillonline.com/content/journals/10.1163/15685411 00002748 .

Kumar, S., Schiffer, P.H. and Blaxter, M. (2012). 959 nematode genomes: a semantic wiki for coordinating sequencing projects. Nucleic Acids Research 40, D1295-D1300. doi: 10.1093/nar/gkr826.

Laing, R., Kikuchi, T., Martinelli, A., Tsai, I. J., Beech, R. N., Redman, E., Holroyd, N., Bartley, D. J., Beasley, H., Britton, C., Curran, D., Devaney, E., Gilabert, A., Hunt, M., Jackson, F., Johnston, S. L., Kryukov, I., Li, K., Morrison, A. A., Reid, A. J., Sargison, N., Saunders, G. I., Wasmuth, J. D., Wolstenholme, A., Berriman, M., Gilleard, J. S. and Cotton, J. A. (2013). The genome and transcriptome of Haemonchus contortus, a key model parasite for drug and vaccine discovery. Genome Biology 14, R88. doi: 10.1186/gb-2013-14-8-r88.

Lambshead, P. J. D. (1993). Recent developments in marine benthic biodiversity research. Oceanis 19, 5-24.

Lambshead, P. J. D. and Boucher, G. (2003). Marine nematode deep-sea biodiversity - hyperdiverse or hype? fournal of Biogeography 30, 475-485. doi: 10.1046/j.1365-2699.2003.00843.x.

Ledger, T. N., Jaubert, S., Bosselut, N., Abad, P. and Rosso, M. N. (2006). Characterization of a new beta-1,4-endoglucanase gene from the root-knot nematode Meloidogyne incognita and evolutionary scheme for phytonematode family 5 glycosyl hydrolases. Gene 382, 121-128.

Lee, C., Chronis, D., Kenning, C., Peret, B., Hewezi, T., Davis, E. L., Baum, T. J., Hussey, R., Bennett, M. and Mitchum, M. G. (2011). The novel cyst nematode effector protein 19C07 interacts with the Arabidopsis auxin influx transporter LAX3 to control feeding site development. Plant Physiology 155, 866-880. doi: 10.1104/pp.110.167197.

Leroy, S., Duperray, C. and Morand, S. (2003). Flow cytometry for parasite nematode genome size measurement. Molecular and Biochemical Parasitology 128, 91-93.

Lohar, D. P. and Bird, D. M. (2003). Lotus japonicus: a new model to study root-parasitic nematodes. Plant and Cell Physiology 44, 1176-1184.

Lu, S. W., Chen, S., Wang, J., Yu, H., Chronis, D., Mitchum, M. G. and Wang, X. (2009). Structural and functional diversity of CLAVATA3/ESR (CLE)-like genes from the potato cyst nematode Globodera rostochiensis. Molecular Plant Microbe Interactions 22, 1128-1142. doi: 10.1094/MPMI22-9-1128.

Martin, J., Abubucker, S., Heizer, E., Taylor, C. M. and Mitreva, M. (2011). Nematode.net update 2011: addition of data sets and tools featuring next-generation sequencing data. Nucleic Acids Research 40, D720-D728. doi: $10.1093 /$ nar/gkr1194

McCarter, J. P. (2009). Molecular approaches toward resistance to plantparasitic nematodes. In Cell Biology of Plant Nematode Parasitism (ed. Berg, R. H. and Taylor, C. G.), pp. 239-267. Springer, Berlin, Germany.

McCarter, J.P., Mitreva, M.D., Martin, J., Dante, M., Wylie, T., Rao, U., Pape, D., Bowers, Y., Theising, B., Murphy, C. V., Kloek, A.P., Chiapelli, B. J., Clifton, S.W., Bird, D.M. and Waterston, R. H. (2003). Analysis and functional classification of transcripts from the nematode Meloidogyne incognita. Genome Biology 4, R26. Mitchum, M. G., Wang, X. and Davis, E. L. (2008). Diverse and conserved roles of CLE peptides. Current Opinion in Plant Biology 11, 75-81. doi: 10.1016/j.pbi.2007.10.010.

Mitreva, M., Jasmer, D. P., Zarlenga, D. S., Wang, Z., Abubucker, S., Martin, J., Taylor, C. M., Yin, Y., Fulton, L., Minx, P., Yang, S.-P., Warren, W. C., Fulton, R. S., Bhonagiri, V., Zhang, X., HallsworthPepin, K., Clifton, S. W., McCarter, J. P., Appleton, J., Mardis, E. R. and Wilson, R.K. (2011). The draft genome of the parasitic nematode Trichinella spiralis. Nature Genetics 43, 228-235. doi: 10.1038/ ng.769. 
Mitreva-Dautova, M., Roze, E., Overmars, H., de Graaff, L., Schots, A., Helder, J., Goverse, A., Bakker, J. and Smant, G. (2006) A symbiont-independent endo-1,4-beta-xylanase from the plant-parasitic nematode Meloidogyne incognita. Molecular Plant Microbe Interactions 19 521-529.

Ni, J., Guo, Y., Jin, H., Hartsell, J. and Clark, S. E. (2011). Characterization of a CLE processing activity. Plant Molecular Biology $\mathbf{7 5}$, 67-75. doi: 10.1007/s11103-010-9708-2.

Nicol, P., Gill, R., Fosu-Nyarko, J. and Jones, M. G. K. (2012). De novo analysis and functional classification of the transcriptome of the roo lesion nematode, Pratylenchus thornei, after 454 GS FLX sequencing. International Fournal for Parasitology 42, 225-237. doi: 10.1016/j. ijpara.2011.11.010

Ohyama, K., Ogawa, M. and Matsubayashi, Y. (2008). Identification of a biologically active, small, secreted peptide in Arabidopsis by in silico gene screening, followed by LC-MS-based structure analysis. Plant Fournal: for Cell and Molecular Biology 55, 152-160. doi: 10.1111/j.1365313X.2008.03464.x.

Oliva, R., Win, J., Raffaele, S., Boutemy, L., Bozkurt, T. O., ChaparroGarcia, A., Segretin, M. E., Stam, R., Schornack, S., Cano, L. M., Van Damme, M., Huitema, E., Thines, M., Banfield, M. J. and Kamoun, S. (2010). Recent developments in effector biology of filamentous plant pathogens: filamentous pathogen effectors. Cellular Microbiology 12, 705-715. doi: 10.1111/j.1462-5822.2010.01471.x.

Olsen, A. N. and Skriver, K. (2003). Ligand mimicry? Plant-parasitic nematode polypeptide with similarity to CLAVATA3. Trends in Plant Science 8, 55-57.

Opperman, C.H., Bird, D. M., Williamson, V.M., Rokhsar, D.S. Burke, M., Cohn, J., Cromer, J., Diener, S., Gajan, J., Graham, S., Houfek, T. D., Liu, Q., Mitros, T., Schaff, J., Schaffer, R., Scholl, E. Sosinski, B. R., Thomas, V. P. and Windham, E. (2008). Sequence and genetic map of Meloidogyne hapla: a compact nematode genome for plan parasitism. Proceedings of the National Academy of Sciences USA 105 14802-14807.

Paganini, J., Campan-Fournier, A., Da Rocha, M., Gouret, P., Pontarotti, P., Wajnberg, E., Abad, P. and Danchin, E. G. J. (2012). Contribution of lateral gene transfers to the genome composition and parasitic ability of root-knot nematodes. PLoS ONE 7, e50875. doi: 10.1371/journal.pone.0050875.

Parkinson, J., Whitton, C., Schmid, R., Thomson, M. and Blaxter, M (2004). NEMBASE: a resource for parasitic nematode ESTs. Nucleic Acids Research 32, D427-D430.

Poinar, G., Kerp, H. and Hass, H. (2008). Palaeonema phyticum gen. n., sp. n. (Nematoda: Palaeonematidae fam. n.), a Devonian nematode associated with early land plants. Nematology 10, 9-14.

Poinar, G. O. (2011). The Evolutionary History of Nematodes: As Revealed in Stone, Amber and Mummies. Brill, Leiden, the Netherlands.

Popeijus, H., Overmars, H., Jones, J., Blok, V., Goverse, A., Helder, J. Schots, A., Bakker, J. and Smant, G. (2000). Degradation of plant cell walls by a nematode. Nature 406, 36-37.

Postma, W. J., Slootweg, E. J., Rehman, S., Finkers-Tomczak, A., Tytgat, T. O. G., van Gelderen, K., Lozano-Torres, J. L., Roosien, J. Pomp, R., van Schaik, C., Bakker, J., Goverse, A. and Smant, G. (2012). The effector SPRYSEC-19 of Globodera rostochiensis suppresse CC-NB-LRR-mediated disease resistance in plants. Plant Physiology $\mathbf{1 6 0}$ 944-954. doi: 10.1104/pp.112.200188.

Qin, L., Kudla, U., Roze, E. H., Goverse, A., Popeijus, H., Nieuwland, J., Overmars, H., Jones, J. T., Schots, A., Smant, G., Bakker, J. and Helder, J. (2004). Plant degradation: a nematode expansin acting on plants. Nature 427,30 .

Robertson, L., López-Pérez, J.A., Bello, A., Díez-Rojo, M. A. Escuer, M., Piedra-Buena, A., Ros, C. and Martínez, C. (2006).
Characterization of Meloidogyne incognita, M. arenaria and M. hapla populations from Spain and Uruguay parasitizing pepper (Capsicum annuum L.). Crop Protection 25, 440-445.

Rosso, M. N., Favery, B., Piotte, C., Arthaud, L., De Boer, J. M., Hussey, R. S., Bakker, J., Baum, T. J. and Abad, P. (1999). Isolation of a cDNA encoding a beta-1,4-endoglucanase in the root-knot nematode Meloidogyne incognita and expression analysis during plant parasitism. Molecular Plant Microbe Interactions 12, 585-591.

Rybarczyk-Mydłowska, K., Mooyman, P., van Megen, H., van den Elsen, S., Vervoort, M., Veenhuizen, P., van Doorn, J., Dees, R., Karssen, G., Bakker, J. and Helder, J. (2012). Small subunit ribosomal DNA-based phylogenetic analysis of foliar nematodes (Aphelenchoides spp.) and their quantitative detection in complex DNA backgrounds. Phytopathology 102, 1153-1160. doi: 10.1094/PHYTO-0512-0114-R.

Sacco, M. A., Koropacka, K., Grenier, E., Jaubert, M. J., Blanchard, A., Goverse, A., Smant, G. and Moffett, P. (2009). The cyst nematode SPRYSEC protein RBP-1 elicits Gpa2- and RanGAP2dependent plant cell death. PLoS Pathogens 5, e1000564. doi: 10.1371/ journal.ppat.1000564.

Schönknecht, G., Weber, A.P.M. and Lercher, M. J. (2014) Horizontal gene acquisitions by eukaryotes as drivers of adaptive evolution. BioEssays 36, 9-20. doi: 10.1002/bies.201300095.

Sharma, V. K., Ramirez, J. and Fletcher, J. C. (2003). The Arabidopsis CLV3-like (CLE) genes are expressed in diverse tissues and encode secreted proteins. Plant Molecular Biology 51, 415-425. doi: 10.1023/ A:1022038932376.

Sikora, S., Strongin, A. and Godzik, A. (2005). Convergent evolution as a mechanism for pathogenic adaptation. Trends in Microbiology 13, 522-527. doi: 10.1016/j.tim.2005.08.010.

Smant, G., Stokkermans, J.P., Yan, Y., de Boer, J. M., Baum, T. J., Wang, X., Hussey, R. S., Gommers, F. J., Henrissat, B., Davis, E. L., Helder, J., Schots, A. and Bakker, J. (1998). Endogenous cellulases in animals: isolation of beta-1, 4-endoglucanase genes from two species of plant-parasitic cyst nematodes. Proceedings of the National Academy of Sciences USA 95, 4906-4911.

Sternberg, P. W. (2005). Vulval development. WormBook. doi: 10.1895/ wormbook.1.6.1.

The C. elegans Genome Sequencing Consortium (1998). Genome sequence of the nematode $C$. elegans: a platform for investigating biology. Science 282, 2012-2018.

Van Megen, H., van den Elsen, S., Holterman, M., Karssen, G., Mooyman, P., Bongers, T., Holovachov, O., Bakker, J. and Helder, J. (2009). A phylogenetic tree of nematodes based on about 1200 full-length small subunit ribosomal DNA sequences. Nematology 11, 927-950.

Wang, J., Lee, C., Replogle, A., Joshi, S., Korkin, D., Hussey, R., Baum, T. J., Davis, E. L., Wang, X. and Mitchum, M. G. (2010). Dual roles for the variable domain in protein trafficking and host-specific recognition of Heterodera glycines CLE effector proteins. New Phytologist 187, 1003-1017. doi: 10.1111/j.1469-8137.2010.03300.x.

Wang, X., Mitchum, M. G., Gao, B., Li, C., Diab, H., Baum, T. J., Hussey, R. S. and Davis, E. L. (2005). A parasitism gene from a plantparasitic nematode with function similar to CLAVATA3/ESR (CLE) of Arabidopsis thaliana. Molecular Plant Pathology 6, 187-191. doi: 10.1111/ j.1364-3703.2005.00270.x.

Watanabe, H. and Tokuda, G. (2010). Cellulolytic systems in insects. Annual Review of Entomology 55, 609-632. doi: 10.1146/annurevento-112408-085319.

Weerasinghe, R.R., Bird, D. M. and Allen, N.S. (2005). Root-knot nematodes and bacterial Nod factors elicit common signal transduction events in Lotus japonicus. Proceedings of the National Academy of Sciences USA 102, 3147-3152. doi: 10.1073/pnas.0407926102. 